\title{
Effect of Drought Stress Conditions and Nitrogen Fertilizer on Growth of Two Cultivars of Wheat (Triticum aestivum $\mathbf{L}$.)
}

\author{
Awad, A; H.M. Abdel-Mottaleb; M.S. Hammada; M.A.A. Kotb and M.G. Abass, \\ Agronomy Department- Faculty of Agriculture - Suez Canal University - Ismailia - Egypt.
}

Received: $29 / 6 / 2015$

\begin{abstract}
Two field experiments were carried out at the Agricultural Experimental farm of Faculty of Agriculture; Suez Canal University; Ismailia Governorate, Egypt during two winter seasons of 2012/13 and 2013/14. These experiments aimed to study the effect of regimes, rates of nitrogen fertilization $(50.75$ and $100 \mathrm{~kg} / \mathrm{fed})$ and two wheat varieties (Sakha 94 and Sedes 12) and their interaction on plant growth characteristics. This experimental farm is located at Longitude $30^{\circ} 58^{\| \prime}$ and Latitude $32^{\circ} 23^{\prime \prime}$ at 13 meter above sea level. The texture of experimental site was sandy soil. Split-split plot design with three replications was followed. Exposure wheat plants to drought stress treatment at tillering or heading stages significantly decreased each of total chlorophyll, carotenoid pigments, plant height, dry weight of biomass above ground/ plant, flag leaf area, leaf area index and crop growth rate at the two growing seasons comparing to control treatment without skipping any irrigation. Meanwhile, proline content was decreased by skipping irrigations at tillering and heading stages. Increasing nitrogen fertilizer up to $100 \mathrm{~kg} \mathrm{~N} / \mathrm{fed} \mathrm{led} \mathrm{to}$ increase all traits under studying during two growing seasons. Wheat cultivar Sakha 94 surpassed Sedes 12 in all traits. Flag leaf area, total chlorophyll and proline contents were affected significantly by interaction between the studied factors.
\end{abstract}

Keywords: wheat, (Triticum aestivum L), cultivars, drought stress.

\section{INTRODUCTION}

Wheat (Triticum aestivum, L) is one of the most important cereal crops in Egypt. Nowadays, wheat production is insufficient to face local consumption as a result of rapidly increase in Egyptian population. Wheat crop is occupied $38.75 \%$ almost from all cultivated area during winter season in Egypt. The same trend is found at Ismailia condition. Some of cultivated areas under wheat crop are suffering from a shortage of irrigation water. Therefore, some of wheat areas will be exposed to drought conditions. Agricultural land of Ismailia is characterized by low the fertility therefore it is necessary to use mineral nitrogen to increase productivity.

Nitrogen is considered one of the most essential factors for high wheat grain yield and its quality. Chlorophyll is the pigment responsible for the green color of plants, and plays a unique role in the physiology of green plants. Therefore, chlorophyll has been used as a sensitive indicator of plant physiology. Status of drought stress (both severe drought and moderate drought) accelerated the chlorophyll content index (CCI) reduction after GF-1 stage i.e. Feekes 11.1, kernels milky ripe (Ommen et al., 1999; Tas and Tas, 2007; Keyvan, 2010; Saeedipour, 2011; Ping et al., 2012). Bojovici and Stojanovic (2005) mentioned that biosynthesis of carotenoids in plants is a genetic characteristic, but environmental conditions play an essential role. Water stress conditions at heading stage increased leaf proline content compared with control treatment (Khan, 2009; Maralian et al., 2010). Negative effect of skipping irrigation at tillering or heading stages could be explained on the light loss of turgor pressure of plant cell which affects rate of cell expansion and ultimate cell size. Loss of turgor is probably the most sensitive process to water stress and resulted in decrement in growth rate and stem elongation (Bayoumi, 1999; Sharaan et al., 2000; Yakout, et al.,
2002; Kotb, 2005; Mehasen et al., 2014). Skipping irrigation has negative effect on dry weight of biomass of wheat plant (Abd El-gawad et al., 1993; Abo- Shetaia and Abd El-gawad, 1995; Yakout et al., 2002; Maralian et al., 2010). Drought stress inhibits cell division and stopping production of new plant tissues and leaf expansion (Yakout et al., 2002; Hassan, 2005; Ping et al., 2012; Mehasen et al., 2014). Drought stress has also negative effect on LAI values and crop growth rate (Abd El-Gawad et al., 1993; Hassan, 2005).

Nitrogen plays an important role in construction of photosynthetic pigments (chlorophyll $\mathrm{a}+\mathrm{b}$ ), as well as carotenoids and increase its concentration into plant cells as increasing nitrogen level (Hassan, 2005; AbdelAti and Zaki, 2006; Tatjana Tranavičienè et al., 2007; Bojovic and Markovic, 2009; Talat, 2013; Karimpour et al., 2013). Proline is one of the amino acids group into plant cell. It well known that any amino acid has amino group (NH2) in its structure and thus increasing nitrogen level into the soil leads to increase absorption of nitrogen into plant cell and thus increases concentration of proline acid in plant tissues (Goudarzi and Pakniyat, 2009; Khan et al., 2009).

Nitrogen play an important role in enhancing some physiological process such as protein formation, cell elongation and cell division, building chlorophyll pigment which resulted in formation of new plant organs and increments of some plant growth characteristic such as plant height, dry matter accumulation flag leaf area, leaf area index (LAI), crop growth rate (CGR) (Shrief et al., 1998; Hassan, 2005; Tatjana Tranaviciene et al., 2007; Ahmed et al., 2012; Gheith et al., 2013; Karimpour et al., 2013).

Wheat varieties are differ in their morphological characteristics (Hassan, 2005; Mohamed et al., 2005; Bayoumi, 2006; Gheith et al., 2013; Masoud Karimpour et al., 2013; Mehasen et al., 2014). 


\section{MATERIALS AND METHODS}

Two field experiments were carried out at the Agricultural Experimental Farm Faculty of Agriculture; Suez Canal University; Ismailia Governorate, Egypt during the two winter seasons of (2012/13 and 2013/14). To study the effect of three irrigation regimes, three rates of nitrogen fertilization and two varieties and their interaction on the plant growth characteristics of wheat. This experimental farm is located at Longitude $30^{\circ} 58^{\|}$and Latitude $32^{\circ} 23^{\|}$at 13 meter above sea level. The climatic conditions of Ismailia city are presented in Table (1) from these data it could be concluded that averages of air temperature during growing season were ranged from $13.4-19.6 \mathrm{C}^{\circ}$ at first season and from $14.5-21.4 \mathrm{C}^{\circ}$ at second season. Ismailia city is characterized by low rain fall during growing season and it was $25 \mathrm{~mm}$ /year. The textures of experimental sites were sandy soil as shown from mechanical and chemical properties in Table (2).

Table (1): Monthly climatic data at Ismailia Governorate during two growing periods of wheat cultivation in $2012 / 2013$ and $2013 / 2014$ seasons.

\begin{tabular}{|c|c|c|c|c|c|}
\hline \multirow[b]{2}{*}{ Date } & \multirow{2}{*}{$\begin{array}{c}\text { Solar radiation Dgt }[\mathrm{MJ} / \mathrm{m} 2] \\
\text { aver }\end{array}$} & \multirow{2}{*}{$\begin{array}{c}\text { Precipitation } \\
\text { [mm] } \\
\text { sum }\end{array}$} & \multicolumn{3}{|c|}{ HC Air temperature $\left[{ }^{\circ} \mathrm{C}\right]$} \\
\hline & & & aver & minimum & maximum \\
\hline \multicolumn{6}{|c|}{$2012 / 2013$ season } \\
\hline December 2012 & 348.58 & 1 & 15.1 & 6.3 & 29.2 \\
\hline January 2013 & 369.51 & 10.2 & 13.4 & 5.4 & 25.9 \\
\hline February 2013 & 494.94 & 2 & 15.5 & 7.1 & 28.2 \\
\hline March 2013 & 656.73 & 0 & 18.5 & 6 & 34.7 \\
\hline April 2013 & 746.74 & 17.6 & 19.6 & 2.5 & 37.2 \\
\hline \multicolumn{6}{|c|}{$2013 / 2014$ season } \\
\hline December 2013 & 438.045 & 0.5 & 18.8 & 9 & 33.4 \\
\hline January 2014 & 377.37 & 7 & 14.8 & 6.45 & 25.95 \\
\hline ]February 2014 & 417.36 & 1.1 & 14.5 & 5.95 & 26.35 \\
\hline March 2014 & 506.03 & 4.8 & 15.3 & 3.8 & 28.85 \\
\hline April 2014 & 777.72 & 0.6 & 21.4 & 11.2 & 35.6 \\
\hline
\end{tabular}

Source: Central Laboratory for Agricultural Climate

Table (2): Mechanical and chemical analysis of experimental soil site in two growing seasons (2012/13 and 2013/14).

\begin{tabular}{|c|c|c|}
\hline Soil analysis & 2012/13 & 2013/14 \\
\hline \multicolumn{3}{|c|}{ Mechanical analysis } \\
\hline Sand $\quad \%$ & 16.98 & 6.91 \\
\hline Silt & 2.32 & 1.73 \\
\hline Clay $\quad \%$ & 80.70 & 91.36 \\
\hline Texture grade & Sandy & Sandy \\
\hline \multicolumn{3}{|c|}{ Chemical analysis } \\
\hline $\mathrm{pH}$ & 7.83 & 7.80 \\
\hline $\operatorname{ECs}\left(\mathrm{ds} \mathrm{m}^{-1}\right)$ & 0.76 & 0.54 \\
\hline $\mathrm{Ca}(\mathrm{meq} / \mathrm{L})$ & 2.8 & 3.0 \\
\hline $\mathrm{Mg}(\mathrm{meq} / \mathrm{L})$ & 2.0 & 1.0 \\
\hline $\mathrm{K}(\mathrm{meq} / \mathrm{L})$ & 0.3 & 0.2 \\
\hline $\mathrm{Na}(\mathrm{meq} / \mathrm{L})$ & 2.9 & 1.8 \\
\hline $\mathrm{Cl}(\mathrm{meq} / \mathrm{L})$ & 3.6 & 1.8 \\
\hline $\mathrm{HCo}_{3}(\mathrm{meq} / \mathrm{L})$ & 4.0 & 3.6 \\
\hline $\mathrm{SO}_{4}(\mathrm{meq} / \mathrm{L})$ & 0.4 & 0.6 \\
\hline $\mathrm{CO}_{3}(\mathrm{meq} / \mathrm{L})$ & 0.0 & 0.0 \\
\hline
\end{tabular}

Factors of study

A-Irrigation regimes: It was three irrigation regimes as following:
1- Normal irrigation regime is considered as a control treatment (without skipping any irrigation treatment).

2- Skipping irrigation treatment during tillering stage.

3- Skipping irrigation treatment during heading stage.

Skipping one irrigation.

B- Fertilization treatments were as following

1 - $50 \mathrm{Kg} \mathrm{N} /$ fed $(119.0 \mathrm{~kg} / \mathrm{ha})$.

2- $75 \mathrm{Kg} \mathrm{N} /$ fed $(178.6 \mathrm{~kg} / \mathrm{ha})$.

3- $100 \mathrm{Kg} \mathrm{N} /$ fed $(238.1 \mathrm{~kg} / \mathrm{ha})$.

Nitrogen fertilizer in form of ammonium nitrate (33.5

N) was used. Each fertilizer rate under study was divided into three doses first dose was $20 \%$ from total quantity and applied at sowing before first irrigation, second dose was $40 \%$ from total quantity and applied after 35 days from first one meanwhile third one was $40 \%$ and applied after 29 days from second one.

$\mathrm{C}$ - The two varieties were

1- Sedes 12

2- Sakha 94

The two varieties of this study were obtained from Ministry of agriculture-Egypt.

Experimental work:

Experiments were laid out in a split- split plot design with three replications whereas irrigation regimes were laid in the main plots, meanwhile fertilization treatments were applied in subplots and finally varieties were 
cultivated in sub-sub plots. Sowing date was December 7, 2012 in first season and December 2, 2013 in second season .Sub-subplot area was $3.5 \mathrm{~m}$ in length and $3 \mathrm{~m}$ in width. Wheat cultivars were sown in sub-sub plot into 15 rows and distance between each two rows was 20 $\mathrm{cm}$. Soil site of experiment was fertilized with phosphorus and potassium fertilizers as recommended and other agronomic practices were applied as followed in Ismailia area. Wheat plants were harvested at April 20, 2013 and April 16, 2014 for first and second season, respectively.

\section{Studied characters:}

After conducting experimental treatments of this study five guarded plants were collected randomly to measure some vegetative growth after 116 days characters as follows:

1- Plant height $(\mathrm{cm})$.

2- Dry weight of biomass above ground (g/plant).

3- Flag leaf area ( $\mathrm{cm}^{2} /$ plant) by using equation of Owen (1968).

4- Leaf area index (LAI/plant)

5- Crop growth rate $\left(\mathrm{mg} / \mathrm{m}^{2} /\right.$ day $)$.

6- Photosynthetic pigments (Chlorophyll a, b and carotenoids) were estimated from green leaf according to Fadeel method (1962) and using formula of Wettstein, (1957).

7- Free proline content

Free proline was determined according to Bates et al (1973).

\section{Statistical analysis:}

All measurements of this study were analyzed by using appropriate analysis of variance (ANOVA) for three factorial experiment in split-split plot design with three replications; where irrigation regimes are in the main factor, nitrogen fertilizer rates as the split factor and wheat varieties as the split-split factor. Statistical analysis was done using the COSTAT system for Windows, version 6.311 (cohort software, Berkeley, CA, USA). Duncan's multiple test was used to differentiate between the averages of each factor in this study. In Duncan's multiple test, significance difference between averages was judged by using alphabets at level of 0.05 (Duncan, 1955).

\section{RESULTS AND DISCUSSION}

The results will be demonstrated under the following topics

\section{I- Effect of skipping (withholding) irrigation treatments at tillering and heading stages of wheat plant.}

Data in Table (3) show that total chlorophyll was decreased by 13.22 and $21.61 \%$ with skipping irrigation at tillering stage for two growing seasons, respectively meanwhile these decrements were 18.97 and $19.05 \%$ by skipping irrigation at heading stage for the growing seasons, respectively comparing to concentration of total chlorophyll of control treatment (Ping et al., 2012; Ommen et al., 1999; Tas and Tas, 2007; Keyvan, 2010; Saeedipour, 2011). Carotenoid pigment was unaffected significantly in the first growing season but at the second one it was decreased significantly by skipping irrigation at tillering or heading stages comparatively to control treatment .Reduction in carotenoids content as a result of water stress was reported by Bojovici and Stojanovic (2005).

Concentration of proline in green leaves was significantly increased by skipping irrigation at tillering or heading stages. At first season, proline content in green leaves was increased significantly by 33.48 and $65.48 \%$ for treatment of skipping irrigation at tillering and heading stages, respectively. The same rend could be observed at second season whereas the percentages of increasing proline content were 30.93 and $57.08 \%$ for same stages, respectively. It could be noticed that concentration of proline was significantly increased at heading stage more than at tillering stage. These increases in concentration of proline content were calculated comparing to control treatment. Similar trend which reported by Khan (2009), Goudarzi and Pakniyat (2009), Khan et al. (2009) and Maralian et al. (2010). They suggested that proline accumulation has beneficial role in osmotic adjustment and protect cell membranes and protein without interfering with macromolecules and behaved as protector of the osmotic pressure.

Data in Table (3) show that exposure wheat plants to drought stress treatment at tillering or heading stages each of plant height, dry weight of biomass above ground/plant, flag leaf area, leaf area index and crop growth rate at two growing seasons significantly decreased compared to control treatment. The existing data in Table (3) show that those traits under investigation were more influenced by skipping irrigation at tillering stage than those of skipping irrigation at heading stage during two growing seasons. The negative effect of skipping irrigation at tillering or heading stages could be explained on the light of loss of turgor pressure of plant cell which affects rate of cell expansion and ultimate cell size. Loss of turgor is probably the most sensitive process to water stress and resulted in decrement in growth rate and stem elongation in addition to stop growing new roots hairs as a result of exposure root plant to water stress by lacking soil moisture (Mehasen et al., 2014). Similar results were also reported by Abd El-gawad et al. (1993), Abo-Shetaia and Abd El-Gawad (1995), Bayoumi (1999), Sharaan et al. (2000), Yakout et al. (2002), Hassan (2005), Kotb (2005), Maralian et al. (2010), Ping et al. (2012) and Mehasen et al. (2014).

II- Effect of nitrogen fertilization levels on photosynthetic pigments and some plant growth characteristics of wheat plant.

Data in Table( 4 ) show that total chlorophyll $(\mathrm{a}+\mathrm{b})$ content in green leaves of wheat plants has significantly increased by increasing nitrogen fertilizer rates up to $100 \mathrm{~kg} \mathrm{~N} /$ feddan during the two seasons. In comparison to lowest rate of nitrogen fertilizer $(50 \mathrm{~kg} / \mathrm{fed}$.), concentration of total chlorophyll pigment was increased by 15.55 and $13.81 \%$ as a result of applying $75 \mathrm{~kg} \mathrm{~N} /$ fed at first and second season, respectively. It could be noticed from data in total chlorophyll pigment continued to be increased by increasing nitrogen fertilizer level up to $100 \mathrm{~kg} / \mathrm{fed}$. The rate of increase 
was 29.63 and $22.86 \%$ for first and second season, respectively. This increase in chlorophyll content may be due to that nitrogen element is enters in structure of chlorophyll molecule and therefore any increase in nitrogen will be resulted in an increase in chlorophyll content into plant cell. Data in Table (4) show that concentration of carotenoids in wheat green leaves was significantly increased by increasing nitrogen fertilizer level up to $100 \mathrm{~kg}$ /feddan and performance of this trait was similar to that of chlorophyll pigments. Similar results were reported by Hassan (2005), Abdel-Ati and Zaki (2006), Tatjana Tranavičienè et al. (2007), Bojovic and Markovic (2009), AsqaTalat (2013) and Karimpour et al. (2013).

Proline in fresh weight of wheat plant was significantly increased by increasing nitrogen fertilizer at two growing seasons (Table 4). Application of $100 \mathrm{~kg}$ $\mathrm{N} /$ fed increased proline accumulation by 31.40 and $39.21 \%$ in comparison to that of $50 \mathrm{~kg} \mathrm{~N} / \mathrm{fed}$ at first and second seasons, respectively. Carotenoids play an important role in photochemical reactions where it's considered as a filter to protect chlorophyll from demolition and dissolution under intense illumination levels (Morsi and Fayed, 1979).

Table (3): Effect of irrigation regimes on some vegetative characteristics of wheat in two growing seasons $2012 / 2013$ and 2013-2014.

\begin{tabular}{|c|c|c|}
\hline & Season 2012-2013 & Season 2013-2014 \\
\hline \multicolumn{3}{|c|}{ Chlorophyll a+b (mg/g leaf fresh weight) } \\
\hline control & $1.75 \mathrm{a}$ & $2.73 a$ \\
\hline Skipping in tillering stage & $1.34 \mathrm{c}$ & $2.14 b$ \\
\hline Skipping in flowering stage & $1.56 \mathrm{~b}$ & $2.21 b$ \\
\hline \multicolumn{3}{|c|}{ Carotenoids (mg/g leaf fresh weight) } \\
\hline control & $0.404 \mathrm{a}$ & $0.842 \mathrm{a}$ \\
\hline Skipping in tillering stage & $0.305 \mathrm{a}$ & $0.588 \mathrm{~b}$ \\
\hline Skipping in flowering stage & $0.316 \mathrm{a}$ & $0.648 b$ \\
\hline \multicolumn{3}{|c|}{ Proline (mg/100g fresh weight) } \\
\hline control & $11.59 \mathrm{c}$ & $13.77 \mathrm{c}$ \\
\hline Skipping in tillering stage & $15.47 b$ & $18.03 \mathrm{~b}$ \\
\hline Skipping in flowering stage & $19.18 \mathrm{a}$ & $21.63 \mathrm{a}$ \\
\hline \multicolumn{3}{|c|}{ Plant height (cm) } \\
\hline control & $96.57 \mathrm{a}$ & $89.03 \mathrm{a}$ \\
\hline Skipping in tillering stage & $84.76 \mathrm{c}$ & $77.81 \mathrm{c}$ \\
\hline Skipping in flowering stage & $92.61 b$ & $83.67 b$ \\
\hline \multicolumn{3}{|c|}{ Total dry weight/plant (g) } \\
\hline control & $3.25 \mathrm{a}$ & $4.62 \mathrm{a}$ \\
\hline Skipping in tillering stage & $2.31 \mathrm{~b}$ & $3.61 b$ \\
\hline Skipping in flowering stage & $2.33 b$ & $3.56 b$ \\
\hline \multicolumn{3}{|c|}{ Flag leaf area $\left(\mathrm{cm}^{2} /\right.$ plant $)$} \\
\hline control & $34.27 \mathrm{a}$ & $24.90 \mathrm{a}$ \\
\hline Skipping in tillering stage & $23.53 \mathrm{c}$ & $16.75 b$ \\
\hline Skipping in flowering stage & $29.21 b$ & $20.92 \mathrm{ab}$ \\
\hline \multicolumn{3}{|c|}{ L.A.I } \\
\hline control & $13.53 \mathrm{a}$ & $17.12 \mathrm{a}$ \\
\hline Skipping in tillering stage & $09.73 b$ & $11.51 \mathrm{c}$ \\
\hline Skipping in flowering stage & $11.07 \mathrm{~b}$ & $14.22 b$ \\
\hline \multicolumn{3}{|c|}{ C.G.R(mg/m2/ day) } \\
\hline control & $9 \mathrm{a}$ & $12 \mathrm{a}$ \\
\hline Skipping in tillering stage & $6 b$ & $9 \mathrm{~b}$ \\
\hline Skipping in flowering stage & $6 b$ & $9 b$ \\
\hline
\end{tabular}


Table (4): Effect of $\mathrm{N}$ fertilization on some vegetative characteristics of wheat in two growing seasons 2012/2013 and 2013-2014

\begin{tabular}{lcc}
\hline & Season 2012-2013 & Season 2013-2014 \\
\hline $\mathbf{5 0} \mathbf{~ k g ~ N / f e d ~}$ & Chlorophyll a+b (mg/g leaf fresh weight) & \\
$\mathbf{7 5} \mathbf{~ k g ~ N / f e d ~}$ & $1.73 \mathrm{~b}$ & $2.10 \mathrm{~b}$ \\
$\mathbf{1 0 0} \mathbf{~ k g ~ N / f e d ~}$ & $1.53 \mathrm{ab}$ & $2.39 \mathrm{a}$ \\
\hline & $1.39 \mathrm{a}$ & $2.58 \mathrm{a}$ \\
\hline $\mathbf{5 0} \mathbf{~ k g ~ N / f e d ~}$ & Carotenoids (mg/g leaf fresh weight) \\
$\mathbf{7 5} \mathbf{~} \mathbf{~ N} /$ fed & $0.318 \mathrm{~b}$ & $0.608 \mathrm{~b}$ \\
$\mathbf{1 0 0} \mathbf{~ k g ~ N / f e d ~}$ & $0.314 \mathrm{~b}$ & $0.637 \mathrm{~b}$ \\
\hline
\end{tabular}

\begin{tabular}{lcc}
\hline & Proline (mg/100g fresh weight) & \\
\hline $\mathbf{5 0} \mathbf{~ k g ~ N / f e d ~}$ & $13.60 \mathrm{~b}$ & $15.02 \mathrm{~b}$ \\
$\mathbf{7 5} \mathbf{~ k g ~ N / f e d ~}$ & $14.77 \mathrm{~b}$ & $17.50 \mathrm{~b}$ \\
$\mathbf{1 0 0} \mathbf{~ k g ~ N / f e d ~}$ & $17.87 \mathrm{a}$ & $20.91 \mathrm{a}$ \\
\hline & Plant height (cm) & \\
\hline $\mathbf{5 0} \mathbf{~ k g ~ N / f e d ~}$ & $84.00 \mathrm{c}$ & $77.24 \mathrm{c}$ \\
$\mathbf{7 5} \mathbf{~ k g ~ N / f e d ~}$ & $92.79 \mathrm{~b}$ & $83.25 \mathrm{~b}$ \\
$\mathbf{1 0 0} \mathbf{~ k g ~ N / f e d ~}$ & $97.14 \mathrm{a}$ & $90.01 \mathrm{a}$
\end{tabular}

\begin{tabular}{|c|c|c|}
\hline \multicolumn{3}{|c|}{ Total dry weight/plant (g) } \\
\hline $50 \mathrm{~kg} \mathrm{~N} /$ fed & $2.21 \mathrm{~b}$ & $3.24 b$ \\
\hline $75 \mathrm{~kg} \mathrm{~N} /$ fed & $2.79 \mathrm{a}$ & $3.95 \mathrm{a}$ \\
\hline $100 \mathrm{~kg} \mathrm{~N} /$ fed & $2.88 \mathrm{a}$ & $4.59 \mathrm{a}$ \\
\hline \multicolumn{3}{|c|}{ Flag leaf area $\left(\mathrm{cm}^{2}\right)$} \\
\hline $50 \mathrm{~kg} \mathrm{~N} /$ fed & $23.09 \mathrm{c}$ & $17.68 \mathrm{c}$ \\
\hline $75 \mathrm{~kg} \mathrm{~N} / \mathrm{fed}$ & $28.10 \mathrm{~b}$ & $20.72 b$ \\
\hline $100 \mathrm{~kg} \mathrm{~N} /$ fed & $35.82 \mathrm{a}$ & $24.16 \mathrm{a}$ \\
\hline \multicolumn{3}{|c|}{ L.A.I } \\
\hline $50 \mathrm{~kg} \mathrm{~N} / \mathrm{fed}$ & $9.43 b$ & $10.77 \mathrm{c}$ \\
\hline $75 \mathrm{~kg} \mathrm{~N} / \mathrm{fed}$ & $11.89 \mathrm{a}$ & $13.54 \mathrm{~b}$ \\
\hline $100 \mathrm{~kg} \mathrm{~N} / \mathrm{fed}$ & $13.01 \mathrm{a}$ & $18.54 \mathrm{a}$ \\
\hline \multicolumn{3}{|c|}{ C.G.R(mg/m2/ day) } \\
\hline $50 \mathrm{~kg} \mathrm{~N} /$ fed & $5 b$ & $9 \mathrm{c}$ \\
\hline $75 \mathrm{~kg} \mathrm{~N} / \mathrm{fed}$ & $7 \mathrm{a}$ & $1 b$ \\
\hline $100 \mathrm{~kg} \mathrm{~N} /$ fed & $8 \mathrm{a}$ & $12 \mathrm{a}$ \\
\hline
\end{tabular}

Data in Table (4) also, showed that applying highest nitrogen rate i.e. $100 \mathrm{~kg} \mathrm{~N} /$ fed increased proline accumulation by 20.99 and $19.49 \%$ comparatively to that of $75 \mathrm{~kg} \mathrm{~N} / \mathrm{fed}$ at first and second seasons, respectively. Proline is one of the amino acids group into plant cell. It well known that any amino acid has amino group $\left(\mathrm{NH}_{2}\right)$ in its structure and thus increasing nitrogen level into the soil leads to increase absorption of nitrogen into plant cell and thus increases concentration of proline acid in plant tissues. These results similar to this of Goudarzi and Pakniyat (2009) and Khan et al. (2009).

Data in Table (4) show that plant growth characters under study i.e. plant height, dry weight of biomass above ground/plant, flag leaf area, leaf area index and crop growth rate were improved significantly and consequently by increasing nitrogen fertilizer level up to $100 \mathrm{~kg} /$ feddan during two growing seasons. These increases in plant growth characteristics may be due to role of nitrogen in enhancing some physiological processes such as cell elongation, cell division and protein formation which turned on increments and improvement of plant growth characteristics and formation of more plant organs. This promoting effect of nitrogen on growth of wheat plant was in harmony with those reported by Sharief et al. (1998), Hassan (2005), Tatjana Tranaviciene et al. (2007), Ahmed et al. (2012), Gheith et al. (2013) and Masoud Karimpour et al. (2013).

\section{III- Varietal differences:-}

Data in Table (5) show that two studied varieties Sakha 94 and Sedes 12 were differed significantly in photosynthetic pigments i.e. total chlorophyll and carotenoids of fresh green leaves whereas statistical 
analysis revealed that wheat variety Sakha 94 surpassed other studied variety Sedes 12 in photosynthetic pigments during two growing seasons. These results are in agreement with the findings of Khan et al. (2009), Zhang et al. (2009) and Talat et al. (2013).

Concerning to proline content in green leaves data in Table (5) show that wheat variety Sakha 94 was higher statistically than that of variety Sedes 12 during two growing seasons. Whereas proline content in green leaves of Sakha 94 were recorded 17.37 and 19.94 $\mathrm{mg} / 100 \mathrm{~g}$ green leaves at first and second season, respectively. Meanwhile, proline content in green leaves of variety Sides 12 was 13.46 and $15.68 \mathrm{mg} / 100 \mathrm{~g}$ green leaves at first and second season, respectively. These results are in harmony with results obtained by goudarzi and pakniyat (2009), Khan et al. (2009), Talat et al. (2013).

Data in Table (5) showed results of statistical analysis of some morphological characters were studied for two cultivars Sakha 94 and Sedes 12. Sakha 94 cultivar was taller than Sedes 12 cultivar by 8.02 and $7.71 \%$ at first and second season, respectively. Concerning to dry weight of biomass above ground plants of cultivar Sakha 94 of dry weight than plants of sedes 12 cultivar by 14.69 and $30.21 \%$ at first and second seasons, respectively. Both wheat cultivars were differed significantly in flag leaf area where of Sakha 94 cultivar are characterized by largest flag leaf area than those of cultivar Sedes 12 by 51.45 and $29.30 \%$ at first and second seasons, respectively. Results revealed that Sakha 94 cultivar have great values of leaf area index (LAI) and surpassed significantly that Sedes 12 cultivar at two growing season (Table 5).

Leaf area index values of Sakha cultivar were recorded 13.82 and 16.79 at first and second season, respectively meanwhile LAI values of Sedes plants were 9.07 and 11.77 at first and second season, respectively. Both two wheat cultivars under investigation were differ statistically in crop growth rate trait at two growing seasons. Crop growth rate values of Sakha 94 cultivar was higher than that of sedes 12 cultivar where CGR of Sakha 94 were 7 and 12 $\mathrm{mg} / \mathrm{m}^{2} /$ day at first and second season, respectively meanwhile crop growth rate of Sedes 12 plants was 6 and $9 \mathrm{mg} / \mathrm{m}^{2} /$ day at first and second season, respectively. These differences in morphological characters of two studied cultivars may be attributed to genetic differences between them. These results are in agreement with the findings of Hassan (2005), Mohamed et al. (2005), Bayoumi (2006), Gheith et al. (2013), Masoud Karimpour et al. (2013) and Mehasen et al. (2014).

Table (5): Effect of varieties on some vegetative characteristics of wheat in two growing seasons 2012/2013 and 20132014.

\begin{tabular}{|c|c|c|}
\hline & Season 2012-2013 & Season 2013-2014 \\
\hline \multicolumn{3}{|c|}{ Chlorophyll a+b (mg/g leaf fresh weight) } \\
\hline Sakha 94 & $1.71 \mathrm{a}$ & $2.55 \mathrm{a}$ \\
\hline Sedes 12 & $1.39 \mathrm{~b}$ & $2.16 b$ \\
\hline \multicolumn{3}{|c|}{ Carotenoids (mg/g leaf fresh weight) } \\
\hline Sakha 94 & $0.401 \mathrm{a}$ & $0.826 \mathrm{a}$ \\
\hline Sedes 12 & $0.281 b$ & $0.560 \mathrm{~b}$ \\
\hline \multicolumn{3}{|c|}{ Proline (mg/100g fresh weight) } \\
\hline Sakha 94 & $17.37 \mathrm{a}$ & $19.94 a$ \\
\hline Sedes 12 & $13.46 b$ & $15.68 b$ \\
\hline \multicolumn{3}{|c|}{ Plant height (cm) } \\
\hline Sakha 94 & $94.83 \mathrm{a}$ & $86.60 \mathrm{a}$ \\
\hline Sedes 12 & $87.79 b$ & $80.40 b$ \\
\hline \multicolumn{3}{|c|}{ Total dry weight/plant (g) } \\
\hline Sakha 94 & $2.81 \mathrm{a}$ & $4.44 \mathrm{a}$ \\
\hline Sedes 12 & $2.45 \mathrm{~b}$ & $3.41 b$ \\
\hline \multicolumn{3}{|c|}{ Flag leaf area $\left(\mathrm{cm}^{2}\right)$} \\
\hline Sakha 94 & $34.94 \mathrm{a}$ & $23.52 \mathrm{a}$ \\
\hline Sedes 12 & $23.07 \mathrm{~b}$ & $18.19 b$ \\
\hline \multicolumn{3}{|c|}{ L.A.I } \\
\hline Sakha 94 & $13.82 \mathrm{a}$ & $16.79 \mathrm{a}$ \\
\hline Sedes 12 & $9.07 \mathrm{~b}$ & $11.77 \mathrm{~b}$ \\
\hline \multicolumn{3}{|c|}{ C.G.R(mg/m2/ day) } \\
\hline Sakha 94 & $7 \mathrm{a}$ & $12 \mathrm{a}$ \\
\hline Sedes 12 & $6 b$ & $9 b$ \\
\hline
\end{tabular}


IV- Effect of interactions among three factors of study:

The statistical analysis revealed that interaction among three factors did not reach to significant level $(\mathrm{p}=0.05)$ for all studied traits at two growing seasons excluding chlorophyll and proline content of green leaves and flag leaf area at first season in addition to flag leaf area of second season. The data in table (6-a) are showed that chlorophyll content in green leaves of first season was affected significantly by interaction between cultivars and skipping irrigation regimes $(p=0.05)$. Highest chlorophyll content $(1.99 \mathrm{mg} / \mathrm{g}$ green leaf weight) was produced from wheat cultivar Sakha 94 of control treatment i.e. without skipping irrigation meanwhile lowest chlorophyll content was produced from wheat cultivar Sids $12(1.23 \mathrm{mg} / \mathrm{g}$ green leaf weight) and skipping irrigation at tillering stag.

The interaction between nitrogen fertilization levels and skipping irrigation regimes at first season (Table 6-a) produced highest proline content (23.74 $\mathrm{mg} / 100 \mathrm{~g}$ leaves fresh weight) from applying $100 \mathrm{~kg}$ $\mathrm{N} /$ fed and treatment of skipping irrigation at heading stage meanwhile lowest proline content was $11.11 \mathrm{mg} /$ $100 \mathrm{~g}$ leaves fresh weight produced from applying $50 \mathrm{~kg}$ $\mathrm{N} /$ fed and treatment of without skipping irrigation. At first season, flag leaf area was affected statistically $(p=0.05)$ by interaction between nitrogen fertilizer levels and skipping irrigation regimes.

The largest flag leaves area i.e. 25.28 and 27.39 $\mathrm{cm}^{2}$ were produced from control treatment (without skipping irrigation) and fertilization treatments 75 or $100 \mathrm{~kg} \mathrm{~N} /$ fed. (Table 6-a). The data in Table (6-b) show that flag leaf area was affected significantly by interaction between nitrogen fertilization levels and wheat cultivars at both growing seasons where wheat cultivar Sakha 94 produced largest flag leaf area from applying $100 \mathrm{~kg} \mathrm{~N} / \mathrm{fed}$ at two growing seasons. The obtained results are in harmony with finding with Allam (2002), Bayoumi (2006), Gheith (2013) and Mehasen et al. (2014).

Table (6-a): Interactions among three factors of study on some vegetative growth characteristics during two seasons.

\begin{tabular}{|c|c|c|c|}
\hline & Control treatment & Tillering stage & Heading stage \\
\hline \multicolumn{4}{|c|}{ Total chlorophyll (mg/g leaf fresh weight) $2012 / 2013$} \\
\hline Sakha94 & 2.00 & 1.45 & 1.69 \\
\hline Sids12 & 1.50 & 1.23 & 1.44 \\
\hline \multicolumn{4}{|l|}{ L.S.D $(p=.05)=0.25$} \\
\hline \multicolumn{4}{|c|}{ Proline (mg/100g fresh weight) $2012 / 2013$} \\
\hline $50 \mathrm{Kg} \mathrm{N}$ & 11.11 & 13.72 & 15.84 \\
\hline $75 \mathrm{Kg} \mathrm{N}$ & 12.13 & 14.34 & 17.84 \\
\hline $100 \mathrm{Kg} \mathrm{N}$ & 11.53 & 18.35 & 23.74 \\
\hline \multicolumn{4}{|l|}{ L.S.D $(p=.05)=1.65$} \\
\hline \multicolumn{4}{|c|}{ Flag leaf area $\left(\mathrm{cm}^{2}\right) 2013 / 2014$} \\
\hline $50 \mathrm{Kg} \mathrm{N}$ & 22.03 & 14.34 & 16.67 \\
\hline $75 \mathrm{Kg} \mathrm{N}$ & 25.28 & 14.45 & 22.43 \\
\hline $100 \mathrm{Kg} \mathrm{N}$ & 27.39 & 21.45 & 23.66 \\
\hline L.S.D $(p=.05)=5.71$ & & & \\
\hline
\end{tabular}

Table (6-b): Interactions among three factors of study on some vegetative growth characteristics during two seasons.

\begin{tabular}{|c|c|c|c|}
\hline & $50 \mathrm{Kg} \mathrm{N}$ & $75 \mathrm{Kg} \mathrm{N}$ & $100 \mathrm{Kg} \mathrm{N}$ \\
\hline \multicolumn{4}{|c|}{ Flag leaf area $\left(\mathrm{cm}^{2}\right) 2012 / 2013$} \\
\hline Sakha94 & 25.16 & 32.54 & 47.08 \\
\hline Sids12 & 20.98 & 23.66 & 24.56 \\
\hline \multicolumn{4}{|c|}{ L.S.D $(p=.05)=13.12$} \\
\hline \multicolumn{4}{|c|}{ Flag leaf area $\left(\mathrm{cm}^{2}\right) 2013 / 2014$} \\
\hline Sakha94 & 19.68 & 22.45 & 28.42 \\
\hline Sids12 & 15.68 & 18.99 & 19.91 \\
\hline L.S.D $(p=$ & & & \\
\hline
\end{tabular}




\section{REFERENCES}

Abd El-Gawad, A.A., A.M. Abo Shetaia and A.S. Edris (1993). Potential productivity of wheat in Egypt. Yield and attributes of certain wheat cultivars. Ann. of Agric. Sci., Ain Shams Univ., 30(2): 815-833.

Abdel-Ati, A.A. and K.I. Zaki (2006). Productivity of some wheat cultivars in calcareous soils under organic farming and rainfed condition with special reference to plant diseases. J. Agric. Sci. Mansoura Univ., 31(4): 1875-1889.

Abo Shetaia, A.M. and A.A. Abd El-Gawad (1995). Growth, yield and yield attributes of wheat in relation to nitrogen fertilization and withholding and irrigation at different stages of growth. Ann. Agric. Sci., Ain Shams Univ., 40(1): 195-211.

Ahmed, A.A., A.S. El-Henawy and E.B. Belal (2012). effect of chemical nitrogen and compost rates on wheat productivity and soil properties. Minufiya J. Agric. Res., 37(1): 123-137.

Allam, A.Y. (2002). Response of four wheat cultivars to nitrogen fertilization and clipping treatments. Assiut, J. of Agric. Sci., 33(5): 146-157.

Bates, L.S., R.P. Waldern and I.D. Teare (1973). Rapid determined of free praline for water stress studies. Plant and Soil, 39: 205-207.

Bayoumi, T.Y. (2006). Heritability and early generation selection for drought tolerance in bread wheat. Egypt. J. Plant Breed., 10(2): 119-134.

Bayoumi, Y.T. (1999). Variability in morphophysiological characters and its relation to drought tolerance in some field crops. Ph.D. Thesis, Agron. Dept., Fac. Agric., Suez canal Univ. Egypt.

Bojovic, B. and A. Markovic (2009). Correlation between nitrogen and chlorophyll content in wheat (Triticum aestivum L.). Kragujevac J. Sci., 31: 69-74.

Bojovici and Stojanovic, (2005). Chlorophyll and carotenoid content in wheat cultivars as a function of mineral nutrition. Arch. Biol. Sci., Belgrade, 57(4): 283-290.

Duncan, D.B. (1955). Multiple Range and Multiple "F" Tests. Biometrics, 11: 1- 24.

Fadeel, (1962). Location and properties of chloroplast and pigment determination in root. Physiol. Plant 15: $130-147$.

Gheith, El-Sayed, M.S., O.Z. El-Badry and S.A. Wahid (2013). Response of growth and straw yield of some wheat genotypes to sowing dates and nitrogen levels. Zagazig J. Agric. Res., 40(2): 809-815.

Goudarzi, M. and H. Pakniyat (2009). Salinity causes increase in praline and protein content and peroxides activity in wheat cultivars. J. App. Sci., 9(2): 348-353.

Hassan, M.A. (2005). Evaluation of two wheat varieties under different moisture stress and nitrogen fertilization. Egypt. J. Plant Breed., 9(1): 49-64.

Karimpour, M., A. Siosemardeh, H. Fateh, H. Badakhshan and G. Heidari (2013). Effect of nitrogen fertilizer on yield and some physiological charachteristics on two drought resistance and susceptible wheat (Triticum aestivum L.) cultivars in response to water stress. Inti J Farm \& Alli Sci., 2(12): 311-324.

Keyvan, S. (2010). The effect of drought stress on yield, relative water content, praline, soluble carbohydrates and chlorophyll of bread wheat cultivars. J. Ani. Plant Sci., 8(3): 1051-1060.

Khan, M.A., M.U. Shirazi, M.A. Khan, S.M. Mujtaba, E. Islam, S. Mumtaz, A. Shereen, R.U. Ansari and M.Y. Ashraf (2009). Role of praline, K/Na ratio and chlorophyll content in salt tolerance of wheat (Triticum aestivum L.). Pak. J. Bot., 41(2): 633-638.

Kotb, M.A.A. (2005). Effect of foliar application of glycinebetaine on growth and yield of wheat (Triticum Aestivum L.) under water stress. The $11^{\text {th }}$ Conference of Agronomy, Agron. Dept., Fac. Agric., Assiut Univ., Nov., 15-16, pp. 65-79.

Maralian, H., A. Ebadi, T.R. Didar and B. Haji-Eghrari, (2010). Influence of water deficit stress on wheat grain yield and praline accumulation rate. Afric. J. Agric., Res., 5(4): 286-289.

Mehasen, S.A.S., N.Kh. El-Gizawy, A.M. Sharoba and S.A. Soliman (2014). Yield and chemical composition of bread wheat cultivars as affected by some skipping irrigation. Minufiya J. Agric. Res., 39(3): 1009-1018.

Mohamed, S.G.A., S.M.G. Salama and A.M. EL-Aziz (2005). Statistical studies for evaluation some varieties of wheat. J. Agric. Sci. Mansoura Univ., 30(6): 2969-2980.

Morsi, M. and T. Fayed (1979). Photosynthetic efficiency for field crops (in arabic). Egyption Anglo library, pp. 60-93.

Ommen, O., A. Donnelly, S. Vanhoutvin, M.V. Oijen and R. Manderscheid (1999). Chlorophyll content of spring flag leaves grown under elevated $\mathrm{CO} 2$ concentration and other environmental stresses within the ESPACE-wheat project. Eur. J. Agron., 10: 197-203.

Owen, P.C. (1968). A measuring scale for areas of cereal leaves. Exp. Agric.4(4):175-278.

Ping, L.I., W.U. Pute and J. Chen (2012). Evaluation of flag leaf chlorophyll content index in 30 spring wheat genotypes under three irrigation regimes. Aust. J. Crop Sci., 6(6): 1123-1130.

Saeedipour, S. (2011). The relationship between the senescence induced by water deficits and $\mathrm{C}$ remobilization during grain filling in two wheat cultivars differing in drought resistance. Afr. J. Agric. Res., 6: 1990-2001.

Sharaan, A.N., F.S. Abd El-Samie and A.A. Abd ElGawad (2000). Response of wheat varieties to some environmental influences 2-Effect of planting data and drought at different plant stages on yield and its components. $9^{\text {th }}$ Conf. of Agron. 2-3 Septemper, Menofiya, Egypt, pp. 1-16.

Sharief, A.E., S.E. El kalla, A.A. Leilha and H.E.M. Mostafa (1998). Response of some wheat cultivars to nitrogen fertilizer levels and biological fertilization. J. Agric. Sci. Mansoura Univ., 23(12): 5807-5816. 
Talat, A., K. Nawaz, K. Hussian, K.H. Bhatti, E.H. Siddiqi, A. Khalid, S. Anwer and U. Sharif (2013). Foliar application of praline for salt tolerance of two wheat (Triticum aestivum L.) cultivars. World Appl. Sci. J., 22(4): 547-554.

Tas, S. and B. Tas (2007). Some physiological response of drought stress in wheat genotypes with different ploidity in Turkiye. World J. Agric. Sci., 3: 178-183.

Tranaviciene, T., J. Siksnianiene, A. Urbonaviciute, I. Vaguseviciene, G. Samuoliene, P. Duchovskis, and A. Sliesaravicius (2007). Effect of nitrogen fertilizers on wheat photosynthetic pigment and carbohydrate contents. Biologija, 53(4): 80-84.
Wettstein, (1957). Chlorophyll lethal under submikrosvopische Fommech sell-der plastiden. Exp. Cell Res., 12: 427-433.

Yakout, G.M., A. Awad, M.S.H. Youseef and S.E. ElHendawy (2002). Response of wheat crop to certain agricultural practices under new reclaimed land conditions. Egypt, J. Appl. Sci., 17(5): 228-245.

Zhang, K., Z. Fang, Y. Liang and J. Tian (2009). Genetic dissection of chlorophyll content at different growth stages in common wheat. J. Gene., 88(2): 183-189.

$$
\text { تأثير الإجهاد الرطوبي و التسميد الآزوتي علي نمو صنفين من أصناف قمح الخبز }
$$

احمد عوض محمد - حسن محمد عبد المطلب - محمد صبري حمادة علي يوسف - ماهر عبد الله قطب - محمد جمال عباس الإس

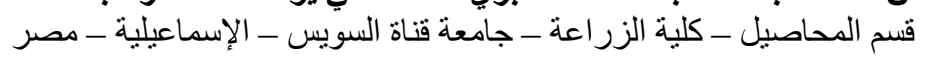

يعتبر محصول القمح المحصول الرئيسي في الغذاء بالنسبة لمصر وفي السنوات الأخيرة تواجه مصر مشكلة بين الإنتاج المحلي

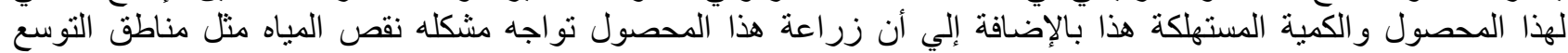

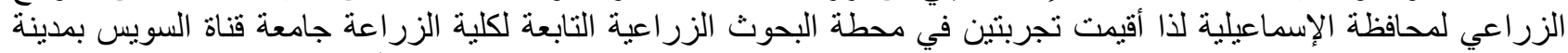

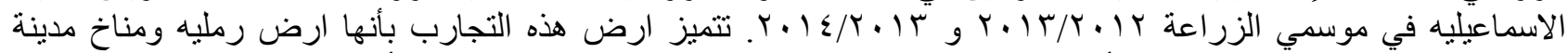

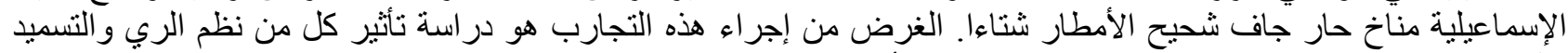

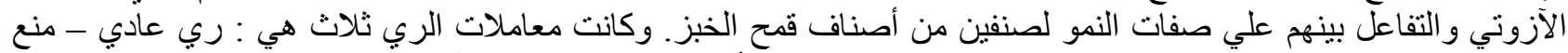

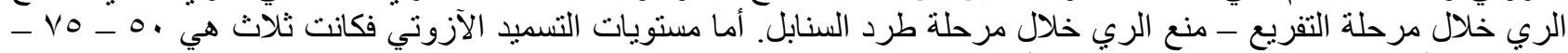

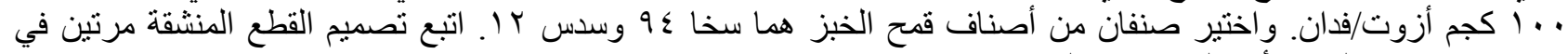

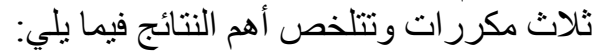
ا ـ أدت معاملة منع الري سواء كان كان في طور التفريع أو طرد السنابل إلي نقص معنوي في كل من صبغات التمثيل الضوئي

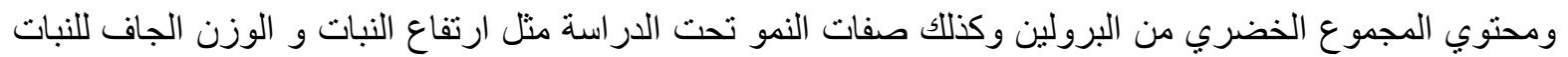

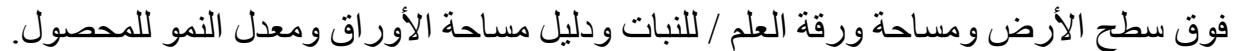

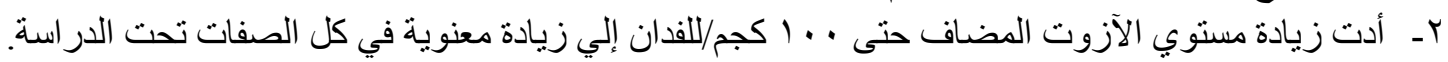

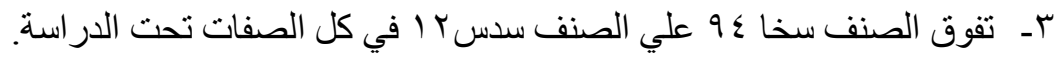

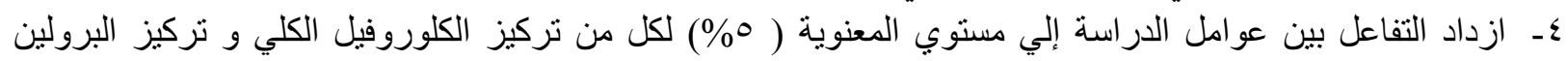
ومساحة ورقة العلم للنبات. 